\title{
SERUM ENZYMES IN HEPATOBILIARY CARCINOMA
}

Priyanka Sharmaํ, Mili Gupta², Gitanjali Goyal³, Kiranjit Kaur ${ }^{4}$

\section{HOW TO CITE THIS ARTICLE:}

Priyanka Sharma, Mili Gupta, Gitanjali Goya, Kiranjit Kaur. "Serum Enzymes in Hepatobiliary Carcinoma". Journal of Evolution of Medical and Dental Sciences 2014; Vol. 3, Issue 09, March 03; Page: 2236-2244,

DOI: $10.14260 /$ jemds/2014/2132

ABSTRACT: INTRODUCTION: Hepatocellular carcinoma (HCC) is the most common primary malignant tumor of the liver. Hepatic metastasis occurs in $40-50 \%$ of adult patients with extrahepatic primary malignancies. The levels of enzymes alkaline phosphatase (ALP), gamma glutamyl transpeptidase (GGT) and leucine aminopeptidase (LAP) are deranged in pathological conditions. AIM: To study and compare the serum enzymes Alkaline phosphatase (ALP), Gamma-glutamyl transpeptidase (GGT) and Leucine aminopeptidase (LAP) in cases of hepatobiliary carcinoma. METHODOLOGY: 30 patients diagnosed with heptobiliary carcinoma were enrolled for the study and 50 healthy individuals of matched age and sex served as controls. Serum Leucine Aminopeptidase (LAP), Alkaline Phosphatase (ALP) and Gamma-glutamyl Transpeptidase (GGT) were determined and compared in study and control groups. RESULTS: The mean levels of serum ALP, GGT and LAP in the study group were $786.3 \pm 465.05 \mathrm{IU} / \mathrm{L}, 193.3 \pm 116.73 \mathrm{IU} / \mathrm{L}$ and $96.86 \pm 34.74 \mathrm{IU} / \mathrm{L}$ respectively. These values were significantly higher than in the control groups. Serum LAP showed abnormal levels in maximum number of cases (93.3\%) followed by serum GGT in $83.3 \%$ and serum ALP in $76.6 \%$ cases. ALP, GGT and LAP levels were significantly higher in icteric and nonicteric groups as compared to control group. CONCLUSIONS: Serum ALP, GGT and LAP were significantly elevated in the patients with hepatobiliary carcinoma and the elevations were significantly higher in icteric as compared to nonicteric groups. Serum LAP is a better indicator of hepatobiliary carcinoma.

KEYWORDS: ALP, GGT, LAP, Hepatobiliary Carcinoma.

INTRODUCTION: Hepatobiliary carcinoma includes carcinoma of liver, pancreas, bile ducts, ampulla of Vater and gall bladder. Hepatocellular carcinoma (HCC) is the most common primary malignant tumor of the liver. It is the fourth most common cancer in the world ${ }^{1}$. Metastases are the most common malignant tumors of the liver ${ }^{2}$. Metastasis of liver is commonest ranking second only to cirrhosis as a cause of liver damage. The incidence of carcinoma of the pancreas has markedly increased over the past several decades and ranks as the fourth leading cause of cancer death in the United States ${ }^{3}$. In pathological conditions there is usually some derangement in the metabolic processes which is reflected by a change in enzymatic patterns. The detection of these biochemical agents is simple and noninvasive.

Leucine aminopeptidase (LAP, 3.4.11.1), a proteolytic enzyme, is capable of hydrolyzing LLeucyl peptides and is primarily involved in protein digestion in small intestine mucosa. LAP is widely distributed in bacteria, plants and distributed in all human tissues with high activity in liver as well as in duodenum, small intestine, pancreas, testis and stromal cells of the uterus ${ }^{4}$. This enzyme is an integral membrane glycoprotein located to apical domain of intestinal epithelial cells. Serum alkaline phosphatase (ALP, 3.1.3.1) is a phosphomonoesterase, which has a widespread distribution in body tissues and is also synthesized in the ductal epithelium in liver. Elevation of serum alkaline phosphatase in liver disease occurs primarily in cholestatic disorders. Gamma glutamyl 
transpeptidase (GGT, 2.3.2.1), is an enzyme located in the membrane of cells which show high secretory or absorptive capacity like epithelial cells lining the biliary tract, hepatic canaliculi, pancreatic acinar tissue, and intestinal brush border cells 5 . GGT participates in transport of amino acids across intracellular membranes as part of gamma glutamyl cycle. In cases of elevated serum levels of gamma glutamyl transpeptidase, the largest contribution is from liver, with little from kidney, pancreas and intestine ${ }^{6}$. The present study attempts to assess the usefulness of serum enzymes alkaline phosphatase (ALP), gamma glutamyl transpeptidase (GGT) and leucine aminopeptidase (LAP) in the diagnosis of hepatobiliary carcinoma.

MATERIALS AND METHODS: The study was done on 30 patients diagnosed with heptobiliary carcinoma visiting surgery and medicine department of Govt. Medical College and Hospital, Patiala. The study was approved by college ethical committee. 50 healthy aged and gender matched adults served as control. Clinically proven cases of hepatobiliary carcinoma, confirmed on radiological investigations, laparotomy, ultrasound, CT scan or MRI were included in the study group. Detailed history was taken and a thorough clinical examination was done. The study group was further divided into icteric and non- icteric groups. All cases which had received chemotherapy, gave history of bone fracture or bone disease in last six months, children, pregnant women and chronic alcoholics were excluded from the study. Serum Leucine Aminopeptidase, Alkaline Phosphatase and Gammaglutamyl transpeptidase were determined using optimized kinetic method.

Investigations done were Hemoglobin (Hb), Total leucocyte count (TLC), Bleeding time(BT), Clotting time (CT), Erythrocyte sedimentation rate (ESR), Fasting blood sugar (FBS), Blood urea, Serum creatinine, TSP, DSP (serum albumin and glopulin), serum amylase, serum bilirubin, Aspartate Transaminase(AST) and Alanine Transaminase(ALT). Serum leucine aminopeptidase (LAP) was determined by optimized kinetic method according to the recommendations of the German society of Clinical Chemistry ${ }^{7}$. When L-leucyl-p-nitroanilide is acted upon by the enzyme leucine aminopeptidase, p-nitroaniline is liberated.

The absorption of p-nitroaniline is very high at $405 \mathrm{~nm}$, whereas the substrate hardly absorbs at all at this wavelength. The absorbance is read at $405 \mathrm{~nm}$ and is directly proportional to the enzyme activity. Reagents: Buffered substrate solution (1.6 mM in 0.05M tris Buffer, pH- 7.2): $40.2 \mathrm{mg}$ of Lleucyl-p-nitroanilide was dissolved in $2 \mathrm{ml}$ of $96 \%$ ethanol and made upto $100 \mathrm{ml}$ with tris buffer. The freshly prepared solution had an absorbance between 0.090 and 0.095 against distilled water at $405 \mathrm{~nm}$. Reagent was freshly prepared each time and was stored in dark colored bottle. Serum ALP was measured by kinetic method and the kit was supplied by Accurex Biomedical Pvt. Ltd., Mumbai. For GGT, the methodology used was of $\mathrm{Ssaz}^{8}$, using single reagent chemistry by kinetic (IFCC) method and the kit used was supplied by Erba/transasia Biomedical Pvt. Ltd., Mumbai. Serum levels were again estimated and compared after one month of treatment in the form of surgery, radiotherapy or chemotherapy.

RESULTS: There was no statistical significant difference in the mean age and sex distribution of study and control groups. Loss of appetite and weight were the main presenting symptoms. (Figure I).Distribution of patients according to diagnosis is depicted in Figure 2. The study group was further divided into icteric and non-icteric groups depending upon the presence or absence of icterus (Figure 3). Serum bilirubin, AST and ALT were found to be significantly higher in study group as compared to 
control group (Table 1). The mean levels of serum ALP, GGT and LAP in the study group before initiation of treatment were $786.3 \pm 465.05 \mathrm{IU} / \mathrm{L}, 193.3 \pm 116.73 \mathrm{IU} / \mathrm{L}$ and $96.86 \pm 34.74 \mathrm{IU} / \mathrm{L}$ respectively. These values were significantly higher than in the control group (Table 2). Out of 30 patients of hepatobiliary carcinoma, serum LAP showed abnormal levels in maximum number of cases (93.3\%) followed by serum GGT in $83.3 \%$ and serum ALP in 76.6\% cases (Table 3).

Thus, it is observed that out of the three enzymes, serum LAP is the most sensitive index of hepatobiliary carcinoma. Levels of all the three enzymes i.e., ALP, GGT and LAP were significantly higher in icteric and non-icteric groups as compared to control group. Also, icteric group showed higher values than the non-icteric group, the difference being highly statistically significant (tables 4 and 5). LAP was significantly raised $(\mathrm{p}<0.001)$ in the icteric as compared to the non-icteric group. 15 out of $16(93.75 \%)$ nonicteric cases had elevated LAP.

This was followed by GGT, raised in 12/16(75\%) nonicteric cases and ALP raised in just $9 / 16(56.25 \%$ ) nonicteric cases. (Table 6). Therefore, it is observed that LAP is the most frequently elevated enzyme in non-icteric patients. The serum levels of ALP, GGT and LAP before and after treatment are compared in table 7 . Out of 30 patients in the study group, only 26 could be followed up because three patients had expired and one refused to follow-up. Though the mean levels of all three enzymes decreased on the follow-up, the difference was not significant statistically.

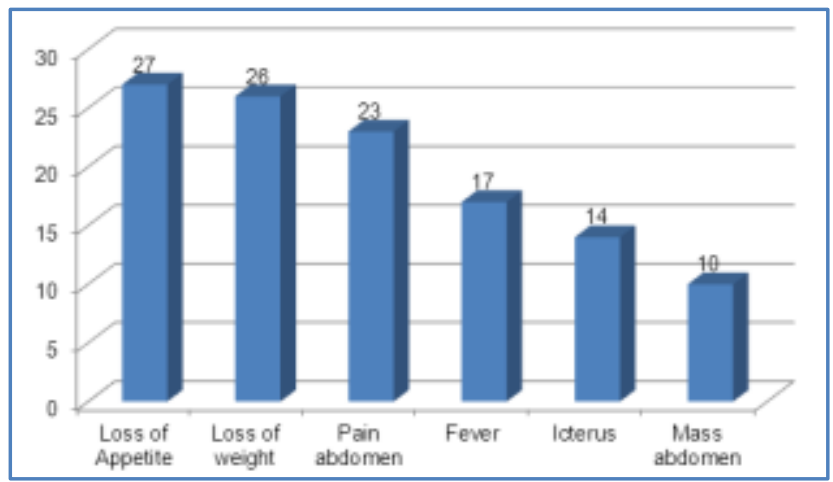

\section{Fig.1: showing distribution of patients according}

to general presenting symptoms

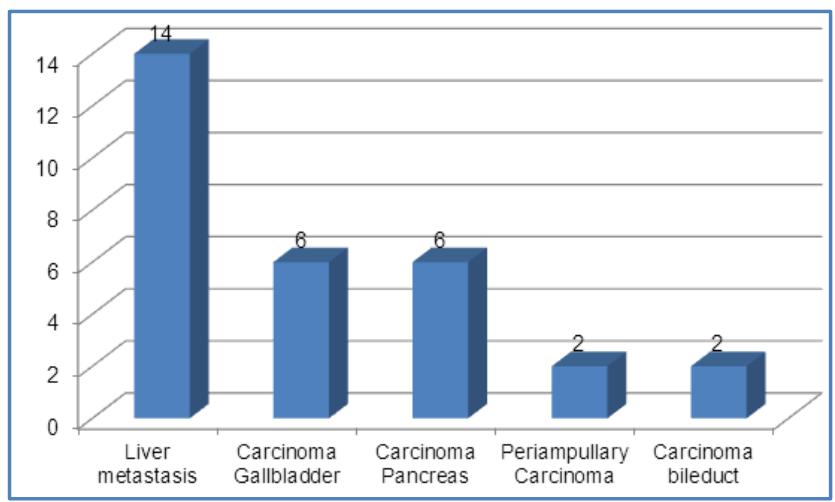

Fig. 2: showing distribution of patients accordingto diagnosis 


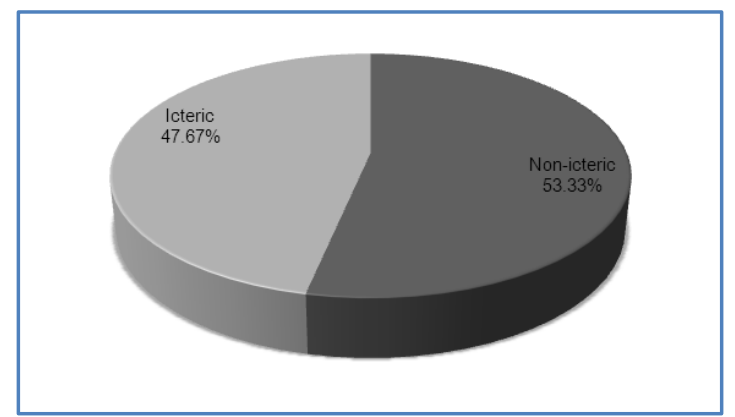

Fig. 3: showing icteric and nonicteric cases of study group

\begin{tabular}{|c|c|c|c|c|c|c|}
\hline Parameter & Group & Range & Mean \pm SD & $\mathbf{t}$ & $\mathbf{p}$ & Significance \\
\hline \multirow{2}{*}{$\begin{array}{c}\text { Bilirubin } \\
\text { (mg \%) }\end{array}$} & Study & $0.4-14.2$ & $3.15 \pm 3.65$ & \multirow{2}{*}{5.16} & \multirow{2}{*}{$<0.001$} & \multirow{2}{*}{ HS } \\
\hline & Control & $0.1-0.9$ & $0.48 \pm 0.19$ & & & \\
\hline \multirow{2}{*}{ AST (IU/L) } & Study & $30-220$ & $107.3 \pm 70.14$ & \multirow{2}{*}{8.63} & \multirow{2}{*}{$<0.001$} & \multirow{2}{*}{ HS } \\
\hline & Control & $10-35$ & $21.26 \pm 7.4$ & & & \\
\hline \multirow{2}{*}{ ALT (IU/L) } & Study & $18-160$ & $67.83 \pm 49.60$ & \multirow{2}{*}{6.30} & \multirow{2}{*}{$<0.001$} & \multirow{2}{*}{ HS } \\
\hline & Control & $12-32$ & $23.18 \pm 6.32$ & & & \\
\hline
\end{tabular}

Table 1: showing serum Bilirubin, AST and ALT levels in study and control groups

\begin{tabular}{|c|c|c|c|c|c|c|c|}
\hline Enzyme & Group & $\begin{array}{c}\text { No. of } \\
\text { Patients }\end{array}$ & $\begin{array}{l}\text { Range } \\
\text { (IU/L) }\end{array}$ & $\begin{array}{c}\text { Mean } \pm \text { SD } \\
(I U / L)\end{array}$ & $\mathbf{t}$ & $\mathbf{p}$ & Significance \\
\hline \multirow{2}{*}{ ALP } & Study & 30 & $220-1650$ & $786.3 \pm 465.05$ & \multirow{2}{*}{9.51} & \multirow{2}{*}{$<0.001$} & \multirow{2}{*}{ HS } \\
\hline & Control & 50 & $112-240$ & $159.48 \pm 38.05$ & & & \\
\hline \multirow{2}{*}{ GGT } & Study & 30 & $30-410$ & $193.3 \pm 116.73$ & \multirow{2}{*}{10.74} & \multirow{2}{*}{$<0.001$} & \multirow{2}{*}{ HS } \\
\hline & Control & 50 & $8-42$ & $16.02 \pm 7.55$ & & & \\
\hline \multirow{2}{*}{ LAP } & Study & 30 & $36-176$ & $96.86 \pm 34.74$ & \multirow{2}{*}{12.87} & \multirow{2}{*}{$<0.001$} & \multirow{2}{*}{ HS } \\
\hline & Control & 50 & $27-40$ & $33.02 \pm 4.41$ & & & \\
\hline
\end{tabular}

\begin{tabular}{|l|c|c|c|c|c|c|}
\hline \multirow{2}{*}{ Level of Enzyme } & \multicolumn{2}{|c|}{ ALP } & \multicolumn{2}{c|}{ GGT } & \multicolumn{2}{c|}{ LAP } \\
\cline { 2 - 7 } & No. & \% age & No. & \% age & No. & \% age \\
\hline Normal & 7 & 23.33 & 5 & 16.67 & 2 & 6.67 \\
\hline Above normal & 23 & 76.67 & 25 & 83.33 & 28 & 93.33 \\
\hline \multicolumn{1}{|c|}{ Total } & 30 & 100 & 30 & 100 & 30 & 100 \\
\hline
\end{tabular}

Table 3: Showing frequency of elevation of serum ALP, GGT and LAP in study group 
ORIGINAL ARTICLE

\begin{tabular}{|c|c|c|c|c|}
\hline Enzyme & $\begin{array}{c}\text { Values } \\
(\mathbf{I U} / \mathbf{L})\end{array}$ & $\begin{array}{c}\text { Control (C) } \\
(\mathbf{n = 5 0})\end{array}$ & $\begin{array}{c}\text { Icteric (I) } \\
(\mathbf{n = 1 4 )}\end{array}$ & $\begin{array}{c}\text { Non-icteric (NI) } \\
(\mathbf{n = 1 6 )}\end{array}$ \\
\hline \multirow{2}{*}{$\mathrm{ALP}$} & Range & $112-240$ & $880-1650$ & $220-860$ \\
\cline { 2 - 5 } & Mean \pm SD & $159.48 \pm 38.05$ & $1215.42 \pm 258.83$ & $410.81 \pm 194.45$ \\
\hline \multirow{2}{*}{ GGT } & Range & $8-42$ & $42-410$ & $30-340$ \\
\cline { 2 - 5 } & Mean \pm SD & $16.02 \pm 7.55$ & $271.78 \pm 100.78$ & $124.62 \pm 82.23$ \\
\hline \multirow{2}{*}{ LAP } & Range & $27-40$ & $38-176$ & $36-150$ \\
\cline { 2 - 5 } & Mean $\pm S D$ & $33.02 \pm 4.41$ & $116.71 \pm 31.64$ & $79.5 \pm 27.87$ \\
\hline
\end{tabular}

Table 4: Comparison of serum ALP, GGT and LAP levels of control group Vs. icteric and non-icteric patients of study group

\begin{tabular}{|c|c|c|c|c|}
\hline Enzyme & Comparison & $\mathbf{t}$ & $\mathbf{P}$ & Significance \\
\hline \multirow{3}{*}{ ALP } & C vs. I & 28.33 & $<0.001$ & HS \\
\cline { 2 - 5 } & C vs. NI & 8.76 & $<0.001$ & HS \\
\cline { 2 - 5 } & I vs. NI & 9.7 & $<0.001$ & HS \\
\hline \multirow{3}{*}{ GGT } & C vs. I & 18.13 & $<0.001$ & HS \\
\cline { 2 - 5 } & C vs. NI & 9.36 & $<0.001$ & HS \\
\cline { 2 - 5 } & I vs. NI & 4.40 & $<0.01$ & HS \\
\hline \multirow{3}{*}{ LAP } & C vs. I & 18.43 & $<0.001$ & HS \\
\cline { 2 - 5 } & C vs. NI & 11.52 & $<0.001$ & HS \\
\cline { 2 - 5 } & I vs. NI & 3.42 & $<0.01$ & HS \\
\hline
\end{tabular}

Table 5: Statistical analysis of comparison of serum ALP, GGT and LAP levels of control group (C) Vs. icteric (I) and non-icteric (NI) patients of study group

\begin{tabular}{|c|c|c|c|c|c|c|c|c|}
\hline \multirow{3}{*}{ Enzyme } & \multicolumn{4}{|c|}{ Icteric (n=14) } & \multicolumn{3}{c|}{ Non-Icteric (n=16) } \\
\cline { 2 - 9 } & \multicolumn{2}{|c|}{ Normal } & \multicolumn{2}{c|}{$\begin{array}{c}\text { Above } \\
\text { Normal }\end{array}$} & \multicolumn{2}{c|}{ Normal } & \multicolumn{2}{c|}{$\begin{array}{c}\text { Above } \\
\text { Normal }\end{array}$} \\
\cline { 2 - 9 } & No. & \% age & No. & \% age & No. & \% age & No. & \% age \\
\hline ALP & - & - & 14 & 100 & 7 & 43.75 & 9 & 56.25 \\
\hline GGT & 1 & 7.14 & 13 & 92.86 & 4 & 25.0 & 12 & 75.0 \\
\hline LAP & 1 & 7.14 & 13 & 92.86 & 1 & 6.25 & 15 & 93.75 \\
\hline
\end{tabular}

Table 6: showing frequency of elevation of serum ALP, GGT and LAP in icteric and non-icteric groups

\begin{tabular}{|c|c|c|c|c|c|c|}
\hline Enzyme & Time & $\begin{array}{c}\text { Mean } \\
\pm \text { SD } \\
\end{array}$ & $\begin{array}{c}\text { Mean } \\
\text { change } \pm S D\end{array}$ & $\mathbf{t}$ & $\mathbf{p}$ & Significance \\
\hline \multirow{2}{*}{ ALP } & Before & $738.03 \pm 439.38$ & \multirow{2}{*}{$177.73 \pm 217.91$} & \multirow{2}{*}{1.62} & \multirow{2}{*}{$>0.05$} & \multirow{2}{*}{ NS } \\
\hline & After & $560.3 \pm 346.4$ & & & & \\
\hline \multirow{2}{*}{ GGT } & Before & $184.76 \pm 118.55$ & \multirow{2}{*}{$50.42 \pm 45.15$} & \multirow{2}{*}{1.74} & \multirow{2}{*}{$>0.05$} & \multirow{2}{*}{ NS } \\
\hline & After & $134.36 \pm 87.26$ & & & & \\
\hline \multirow{2}{*}{ LAP } & Before & $93.5 \pm 33.4$ & \multirow{2}{*}{$16.96 \pm 17.01$} & \multirow{2}{*}{1.94} & \multirow{2}{*}{$>0.05$} & \multirow{2}{*}{ NS } \\
\hline & After & $76.53 \pm 29.51$ & & & & \\
\hline
\end{tabular}


DISCUSSION: The present study was intended to compare the levels of serum enzymes - ALP, GGT and LAP in patients suffering from hepatobiliary carcinoma with the age and gender matched controls, and to note any difference of these enzymes a month after initiation of treatment. Serum ALP levels were found to be a reliable index of metastatic liver disease ${ }^{9-11}$. Monitoring the elevation of ALP levels in patients of colorectal carcinoma may be used as an indicator of subsequent liver metastases ${ }^{12}$.On the contrary, another finding showed that serum ALP does not increase significantly in cases of liver metastasis ${ }^{13}$.Increase in ALP activity also occurs in bone diseases due to increased activity of osteoblasts ${ }^{14,15}$.

It has been suggested that in the hepatobiliary diseases, there is increased synthesis of ALP by the hepatocytes which results in increased enzyme levels in circulation ${ }^{14}$. Hepatic ALP is normally present on the apical domain (i.e., canalicular) of the hepatocyte plasma membrane and in the luminal domain of bile duct epithelium. In cholestasis, retained bile acids solubilize the hepatocyte plasma membrane and facilitate release of ALP16-18. The increase levels of serum GGT result from cholestasis in which the bile acids solubilize the hepatic membrane bound enzyme ${ }^{19,20}$. It is also suggested that the tumor itself may contribute to raised GGT levels because of the pronounced GGT activity of malignant liver cells ${ }^{21,22}$.

Studies from several authors have shown raised levels of serum GGT in liver metastasis ${ }^{10,11 .}$ GGT was increased in most of the patients $(70 \%)$ of liver metastases ${ }^{23}$. Serum GGT is an important marker for Hepatitis B virus-related combined hepatocellular-cholangiocarcinoma ${ }^{24}$. It is shown that serum GGT is not elevated in bone disorders ${ }^{25}, 26$. Thus measurement of serum GGT helps us to distinguish whether bone or liver is the source of increased levels of serum ALP. Elevation of serum GGT levels is an indicator of aggressive tumor behaviors and a predictor of poor clinical outcomes. It may prove to be a useful biomarker for identifying intrahepatic cholangiocarcinoma (ICC) patients at high risk of early recurrence and unfavorableprognosis ${ }^{27}$. Out of the three enzymes, serum LAP was found to be raised in maximum number of cases (93.3\%) followed by GGT and ALP in $83.3 \%$ and $73.3 \%$ cases respectively. LAP is found to be the most sensitive enzyme in hepatobiliary carcinoma ${ }^{28}$.

Abnormal levels of serum LAP were reported in $100 \%$ of cases of carcinoma pancreas and $93 \%$ cases of liver metastasis ${ }^{29}$. LAP is raised in diseases of liver and hepatobiliary duct system and the diseases not involving liver and bile duct system are seldom associated with increased LAP ${ }^{30}$. Increased LAP was due to obstruction of common bile duct by the tumor or liver metastasis or both. Significantly elevated LAP levels were observed in liver metastasis ${ }^{31}, 32$. Arise in serum LAP is detected in patients of hepatobiliary pancreatic carcinoma ${ }^{28}$. LAP was found to be elevated in papillary adenocarcinoma of bile duct ${ }^{33}$ and in cholestatic liver disease ${ }^{34}$.Non-significant elevations of LAP was observed in cases of carcinoma gallbladder without liver metastasis ${ }^{35}$. Serum LAP is not significantly elevated in malignant liver disease as compared to benign liver disease ${ }^{36}$. Patients with liver metastasis of non-pancreatic origin and without jaundice had increased LAP levels suggesting that hepatic infiltration is the cause of rise in liver metastasis ${ }^{29}$.

Cholestatic liver diseases are characterized by impaired hepatocellular secretion of bile, resulting in intracellular accumulation of bile acids which result in a shift in the oxidant/prooxidant balance in favor of increased free radical activity and injury of different tissues ${ }^{37}$.It is concluded that rise in LAP seen in both icteric and non-icteric groups was due to hepatocellular dysfunction. Whereas ALP and GGT showed greater rise in icteric group as compared to non-icteric group indicating that hepatic dysfunction with jaundice was the cause of elevated levels, LAP rises with 
hepatic dysfunction irrespective of jaundice, it is a better indicator of hepatobiliary malignancy ${ }^{28}$. Lowering of LAP levels was either due to removal of primary tumor or suppression of primary tumor with subsequent decrease in size of secondaries by various modes of treatment (surgery, radiotherapy or chemotherapy).

Fall in levels were not statistically significant because the residual tumor still remained in the body. Moreover these estimations were done when patients were still taking the treatment in the form of radiotherapy or chemotherapy and high levels may have not disappeared from the circulation. These patients may have shown fall in the levels after completion of treatment.

CONCLUSIONS: All the three enzymes i.e. ALP, GGT and LAP are significantly elevated in the patients with hepatobiliary carcinoma and the elevations are significantly higher in icteric patients as compared to nonicteric patients. Out of these enzymes, LAP is the most sensitive in diagnosis of hepatobiliary carcinoma. It is more useful in the screening of non-icteric cases of hepatobiliary carcinoma as it rises more frequently in non-icteric cases. Thus serum LAP is a better indicator of hepatobiliary carcinoma. Monitoring LAP is a simple, low cost, and relatively sensitive screening tool for detecting hepatobiliary carcinoma.

\section{REFERENCES:}

1. Parkin DM, Whelan SL, Ferlay J et al. Cancer Incidence in Five Continents. Volume VII. Lyon, France: International Agency for Research on Cancer, 1997.

2. Kasper HU, Drebber U, Dries V, Dienes HP. Liver metastasis: incidence and histogenesis. Z Gastroenterol. 2005 Oct; 43(10):1149-57.

3. Silverman DT, Schiffman M, Everhart J, et al. Diabetes mellitus, other medical conditions and familial history of cancer as risk factors for pancreatic cancer. Br J Cancer 80 (11): 1830-7, 1999. [PUBMED Abstract]Int J Urol. 2007 Apr; 14(4):289-93.

4. Smith EL and Hill RL. Leucine Aminopeptidase. In: The Enzymes Eds. P.D. Boyer, H. Lardy, and K. Myrbak. Academic Press, New York and London Inc. 1960; Vol 4: 37-62

5. Meister A and Anderson ME. Glutathione. Ann Rev Biochem 1983; 52:744-760

6. Husby NE. Separation and character of human GGT. Adv Biochem Pharmacol 1982;3: 47-54

7. Ssaz G. A kinetic photometric method for serum leucine aminopeptidase. Amer J Clin Patho 1967; 24: 607-613.

8. Ssaz G. A kinetic photometric method for serum GGT. Clin Chem 1969; 15: 124-126.

9. Huguier M and Lacaine F. Hepatic metastasis in Gastrointestinal cancer. Arch surg 1981; 116: 399-401

10. Rusia U, Dewan A, Raj GA et al. Enzyme profile in metastatic liver disease. Indian J Med Res 1984; 80: 321-326

11. Yeshowardhan, Singh VS, Pratap VK et al. Serum enzymes in carcinoma gastrointestinal tract. Ind J Cancer 1984; 21: 146-156.

12. M. Wasif Saif, Dominik Alexander, Charles M. Wicox. Serum Alkaline Phosphatase Level as a Prognostic Tool in Colorectal Cancer: A Study of 105 patients. J Appl Res. 2005;5(1): 88-95

13. Pande GK, Sarin R, Kapur BML. Reliability of serum 5'- nucleotidase alkaline phosphatase and liver scan in hepatic metastasis. Indian J of Surg 1992; 54 (5):185-188 
14. Moss DW. Diagnostic aspects of alkaline phosphatase and its isoenzymes. Clin Biochem 1987 Aug; 20 (4):225-230.

15. Ferraz-de-Souza B, Correa PH. Diagnosis and treatment of Paget's disease of bone: a minireview; Arq Bras Endocrinol Metabol. 2013 Nov; 57(8):577-82.

16. Seetharam S, Sussman NL, Kimoda $\mathrm{T}$ et al. The mechanism of elevated alkaline phosphatase activity after bile duct ligation in the rat. Hepatology 1986; 6: 374-380.

17. Hatoff ED, Hardison WGM. Bile acids modify alkaline phosphatase induction and bile secretion pressure after bile duct obstruction in the rat during cholestasis, Gastroenterology 1981; 80: 668-672.

18. Schlaeger R, Haux P, Kattermann R. Studies on the mechanism of the increase in serum alkaline phosphatase activity in cholestasis: significance of the hepatic bile acid concentration for the leakage of alkaline phosphatase from the rat liver. Enzyme 1982; 28: 3-13.

19. Husby NE, Torstein V. The activity of gamma glutamyl-transferase after bile duct ligation in guinea pig. Clin Chem Acta1978; 88: 385-392

20. Hirata E, Inoue M, Morino Y. Mechanism of biliary secretion of membranous enzymes: Bile acids are important factors for biliary occurrence of gamma glutamyl-transferase and other hydrolases. J Biochem 1984; 96:289-297.

21. Kokot F, Kuska J, Grzybex H et al. Gamma glutamyl- transpeptidase in tumour diseases. Arch Immunol. Ther Exptl 1965; 13: 586-592

22. Aronsen KE, Hagerstrand I, Norden JG et al. On the causes of the increased activity of alkaline phosphatase and gamma glutamyl-transferase in serum of patients with liver metastasis. Acta Chir Scand 1969; 135: 619-624

23. Simic T, Dragicevic D, Savic-Radojevic A et al. Serum gamma glutamyl-transferase is a sensitive but unspecific marker of metastatic renal cell carcinoma. J Appl Res.2005; 5(1): 88-95.

24. Chu KJ, Lu CD, Dong Het al. Hepatitis B virus-related combined hepatocellularcholangiocarcinoma: clinicopathological and prognostic analysis of 390 cases. Eur J Gastroenterol Hepatol. 2014 Feb; 26(2):192-9.

25. Betro MG, Oon RCS, Edwards JB. Gamma glutamyl-transferase in diseases of the liver and bone. Am J Clin Pathol 1973; 60: 672-678

26. Lum G and Gambino SR. Serum gamma glutamyl- transpeptidase activity as an indicator of disease of the liver, pancreas and bone. Clinical Chemistry 1972; 18 (4):358-362.

27. Yin X, Zheng SS, Zhang BH et al. Elevation of serum $\gamma$-glutamyl transferase as a predictor of aggressive tumor behaviors and unfavorable prognosis in patients with intrahepatic cholangiocarcinoma: analysis of a large monocenter study; Eur J Gastroenterol Hepatol.2013 Dec; 25(12):1408-14.

28. Ghadge MS, Sirsat AV, Bhansali MS et al. Leucine aminopeptidase a better indicator of carcinoma of liver, biliary tract and Pancreas. Indian Journal of Clinical Biochemistry 2001; 16(1):60-64

29. Bressler R, Forsyth BR, Klatskin G. Serum leucine aminopeptidase activity in hepatobiliary and pancreatic disease. J Lab Clin Med 1960; 56: 417-30.

30. Batsakis JG, Kremers BJ, Thiessen MM et al. "Biliary tract Enzymology." A clinical comparison of serum alkaline phosphatase, leucine aminopeptidase and 5'- nucleotidase. Am J Clin Pathol 1968; $50(4): 485-490$ 
31. Mehrotra TN, Singh VS, Mittal HS et al. Leucine aminopeptidase in gastrointestinal cancers. J Assoc Physicians India 1984;32: 583-584

32. Aziz M, Gupta SK, Khan AA. Serum leucine aminopeptidase profile in cancers of gastrointestinal tract with special reference to hepatic metastasis. J Indian Assoc 1990; 88(6):160-163

33. Mori S, Kasahara M. Papillary adenocarcinoma of the subvesical duct; J Hepatobiliary Pancreat Surg. 2001; 8(5):494-8.

34. Bianda T, Bannwart F, Inderbitzi R, Caduff B. Chronic cholestatic liver disease and grand mal seizures: Dtsch Med Wochenschr.1996 Aug 16; 121(33):1009-14.

35. Sathe SB and Taskar SP. Leucine aminopeptidase levels in hepatic and certain gastrointestinal tract cancers. J Assoc Physicians India 1982 Feb; 30(2): 83.

36. Pasanen P, Pikkarainen P, Alhava E et al. Value of serum alkaline phosphatase, aminotransferase, gamma glutamyl- transferase, leucine aminopeptidase and bilirubin in the distinction between benign and malignant disease causing jaundice and cholestasis: results from a prospective study. Scand J Clin lab Invest 1993; 53:35-39.

37. Somi MH, Kalageychi H, Hajipour B et al. Lipoic acid prevents hepatic and intestinal damage induced by obstruction of the common bile duct in rats; Eur Rev Med Pharmacol Sci. 2013 May;17(10):1305-10.

\section{AUTHORS:}

1. Priyanka Sharma

2. Mili Gupta

3. Gitanjali Goyal

4. Kiranjit Kaur

\section{PARTICULARS OF CONTRIBUTORS:}

1. Assistant Professor, Department of Biochemistry, Maharishi Markendeshwar Medical College and Hospital, Solan, H. P.

2. Associate Professor, Department of Biochemistry, G. G. S. Medical College and Hospital, Faridkot, Punjab.

3. Assistant Professor, Department of Biochemistry, H. S. Judge University College of Dental Sciences, Chandigarh.
4. Professor and Head, Department of Biochemistry, Maharishi Markendeshwar Medical College and Hospital, Solan, H. P.

\section{NAME ADDRESS EMAIL ID OF THE} CORRESPONDING AUTHOR:

Dr. Priyanka Sharma,

H. No. 92, Sector - 33A,

Chandigarh.

E-mail: mintusharma@yahoo.com

Date of Submission: 24/01/2014.

Date of Peer Review: 25/01/2014.

Date of Acceptance: 07/02/2014.

Date of Publishing: 27/02/2014. 